\title{
The VOICES AND ACTIONS OF CHILD ACTIVISTS AgAINST THE CLIMATE CRISIS
}

\author{
Bianca OrRico SERRÃo \\ Institute of Education, Department of Social Sciences and Education, \\ University of Minho \\ R. da Universidade, 4710-057 Braga, Portugal \\ e-mail address: bianca.orrico@gmail.com \\ ORCID: 0000-0002-2777-9881
}

\author{
Manuel Jacinto SARMENTO \\ Department of Social Sciences and Education, Institute of Education, \\ University of Minho \\ R. da Universidade, 4710-057 Braga, Portugal \\ e-mail address: sarmento@ie.uminho.pt \\ ORCID: 0000-0002-6556-9498
}

Juliana Prates Santana

Psychology Department, Institute of Psychology, Federal University of Bahia R. Aristides Novis, 197, Estrada de São Lázaro, CEP 40210-730, Salvador, Bahia, Brazil e-mail address: julianapsantana@gmail.com

ORCID: 0000-0002-3352-9598

\begin{abstract}
Aim. The work has as main objective to present some of the actions of children considered activists to face the climate crisis through social media. Technologies and social media allow them a new form of existence and action through their posts, whether is in video, photo or text format, promoting interactions and discussions that captivate hundreds or thousands of followers.

Methods. Data collection was carried out from a digital ethnography, analysing the social media and linked news in the media of 13 children from different countries (Australia, United States, India, Holland, England, Indonesia, South Africa, Uganda and Sweden) over an 18-month period.

Results. To understand the data, digital ethnography was used as a strategy to follow the main interactions and online mobilisations through different social media (Facebook, Instagram and Twitter), as well as linked news in the media about those children, and articulation of them with governmental, non-governmental organizations and private companies. In relation to the selection of participants, the profile of a child activist was added and through the algorithms of these platforms other activists with similar profiles were found that promote content about climate justice.
\end{abstract}


Conclusions. It was possible to identify that the Internet has enabled the visibility and articulation of children's actions on the theme, and how this engagement has promoted awareness and changes to fight against the climate crisis. It is worth emphasising the importance of digital literacy so that access to these spaces is carried out safely and responsibly for this social group.

Keywords: childhood, activism, climate crisis, influence, digital etnography

\section{INTRODUCTION}

One of the topics of most concern and mentioned by children today is the climate crisis (Unicef, 2013). This children's interest can be directly related to environmental education actions that are carried out in schools. According to the UNESCO Global Educational Monitoring Report (Unesco, 2016), the 2030 Agenda for Sustainable Development prioritises educational aspects, seeking through global development goals to protect the planet through the sustainable production and management of natural resources and urgent actions against climate change so that it can meet the needs of present and future generations.

In Europe, the European Commission through the Eurydice Report (2017) states that axes related to "astainable development" and "environmental protection" are frequently addressed in educational institutions in approximately 29 European countries, the first being more in depth for more advanced students, that is, who are in secondary education and the second, more discussed and taught in primary schools.

With environmental education in schools being increasingly expanded and discussed, children have raised concerns about what has happened and what may happen in the future. It is possible to identify that children are mobilising to intervene, effectively seeking more effective measures to face the climate emergency. According to the annual report of the United Nations Environment Program (Flagship UN study shows accelerating climate change on land, sea and in the atmosphere, 2020), the world is still not fulfilling the commitment to reduce carbon emissions proposed by the Paris Agreement (The Paris Agreement, the international treaty on climate change adopted by 196 Parties at COP 21 in Paris, on 12 December 2015 and entered into force on 4 November 2016, 2016). The uncertainty of a future, so tied to what is thought about the child that is constantly pointed out only from the perspective of becoming an adult, has been on the agenda of this social group in recent years. The damage caused to the environment, by the massive emission of greenhouse gases, accelerated deforestation, increased industrial activities, and inconsequential consumption of natural resources, has caused devastating impacts and no country is immune to the consequences of these changes.

Global warming has been a frequent target of discussions on the political, scientific, and economic agendas, as the rise in temperatures has caused great concern in several sectors of society. According to Scott A. Kulp and Benjamin H. Strauss (2019), with the identification of the temperature rise, it was evaluated that the global vulnerability estimates tripled, mainly due to the sea-level rise due to coastal 
floods. The study points out that as a result of the pollution caused by the increase in temperature, there will be an increase in sea level and the forecast is that in 2100, areas that currently house 200 million people may be permanently below the high tide line, especially in coastal regions of Asia (Kulp \& Strauss, 2019).

In 2007, Unicef published the children's considerations regarding the climate crisis, mentioning in the document their participation in local actions focused on health, agriculture, and the environment, as it affects their survival and development. Through listening to children, the need to conserve and rescue natural resources was identified, awareness of the need to live in healthy environments favorable to their development and accessible and suitable environments for children with special needs. Natural disasters, diseases, lack of food and drinking water, use of renewable energies were some of the axes considered fundamental for assessing and carrying out actions to face this crisis (Unicef, 2007).

Children, being the generation that will be most affected by the climate crisis, are becoming spokespersons to warn about the environmental impacts that have occurred around the world, demanding from the authorities urgent changes for the preservation of the planet and actively participating in actions that they seek to raise awareness about the importance of citizenship to face environmental problems. This citizen participation strategy can be conceptualised, as proposed by Irene Rizzini et al. (2005) as ,(...) a right and an essential component in the exercise of active citizenship. It is the awareness process that results in collective actions to promote citizenship. It refers to legitimate forms of population participation in the public and political sphere" (Rizzini et al., 2005, p. 8).

Citizen participation goes beyond articulation with social movements, parties, and unions, but rather from the multiple conscious experiences that a person has in their own trajectory (Rizzini, Thapliyal, \& Pereira, 2007). With children, this is no different. By having access to information related to the climate crisis, they are organising themselves and looking for resistance strategies to talk about topics that they consider relevant.

Thinking about the participation model presented by Laura Lundy (2015), which seeks to define the categories of space, voice, hearing, and influence as elements that support the right to participation of children as set out in Article 12 of the Child Rights Convention, it is necessary to understand, that space must be safe and inclusive so that children can express themselves; that for their voice to be expressed, it is essential that they can have access to the information needed to form their own opinion; that the audience must ensure that the child's voice is validated; and that the influence will allow the child's opinion to result, when possible, in action on a given situation or cause, promoting through this category, the effective participation of the child and expansion of the principle of democracy (Lundy, 2015).

Technologies and social media allow them a new form of existence and action through their posts, whether is in video, photo, or text format, promoting interactions and discussions that captivate diverse followers (Miller et al., 2016). Even though adults are not considered the most appropriate and safe space for the presence of children, and still not being fully inclusive, since not all children have 
access to the Internet and technologies, it is mainly through the Internet that this social group has access to information (which is also considered risky due to the circulation of fake news on these platforms) and promoted mobilisations, in some cases, be accompanied by hundreds and sometimes thousands of people, using their influence and visibility to address social issues that they consider relevant. In this work, the actions and positions of child activists who use digital platforms to raise awareness and make their peers aware of the importance of social mobilisation to face the climate crisis will be presented.

\section{METHOD}

To understand the data, digital ethnography was used as a strategy to follow the main interactions and online mobilisations through different social media (Facebook, Instagram, and Twitter), articulation of children with governmental, non-governmental organisations, and private companies, as well as linked news in the media about children during the 18 months (May 2019 to December 2020). About the selection of participants, the profile of a child activist was added and through the algorithms of these platforms that suggest similar profiles, other children were identified who for use these spaces to promote content about the topic, with children with profiles with more than 2000 followers. A total that 13 children (12 girls and 1 boy) from different countries (Australia, United States, India, Holland, England, Indonesia, South Africa, Uganda, and Sweden) were investigated to carry out this work, being considered in this analysis, gender, race, and nationality. It was not possible to identify precisely the social class of the investigated participants. Digital ethnography proved to be a very pertinent technique, as it allows direct observation of publications made on social media and interviews with children in different news, in addition to a critical analysis of the phenomena that involve visibility and activism in the digital space.

According to Dhiraj Murthy (2008), digital ethnography makes it easier to store and retrieve data, promotes the greater expansion of qualitative analysis, in addition to allowing the observation of a variety of participants, as well as enabling the identification and collection of data and comments in a more agile and instantaneous way. For Nikhilesh Dholakia and Dong Zhang (2004), another important advantage of digital ethnography is to establish an observation that does not influence the behaviour of the participants, since it is through the "the anonymity of the researcher, which allows a peek at the online communications environment, leading to a true non-obstructive observation [...] The discreet nature of qualitative Internet-based research removes such demand artifacts and perceived pressures on the research subjects" (Dholakia \& Zhang., 2004, p. 5).

However, it is worth noting that as a disadvantage, this form of ethnography excludes a large portion of the voices of children who do not have access to social media or who do not use online platforms to publicly publicise their actions. Understanding that online spaces are fundamental to understanding how con- 
temporary childhood works, publications and news linked in the media about the actions of children who consider themselves to be climate activists will be presented. The aim is to broaden their voice on the issues surrounding their struggles and interests and to reinforce the importance of viewing them as complete and competent human beings.

\section{Results}

The most well-known case currently started in 2018, through a global movement called Fridays for future (Fridays for Future is a youth-led and organised global climate strike movement that started in August 2018 started by Greta Thunberg in Swedish, 2018)., started by a caucasian Swedish girl who was then 15 years old, called Greta Thunberg. This movement aimed to carry out a school strike for three weeks to demand effective actions from the government to combat the climate crisis. Greta went alone to the front of the Swedish parliament and after posting on social media and other media outlets, she did not continue alone. Other children joined her and since her mobilisation, school strikes are held every Friday to protest about climate change.

With the movement's visibility on social media, children around the world got organised and started to articulate in their cities to participate in the protests. Greta began to be considered an influential digital activist, for being followed on her social platforms by thousands of people (currently she is followed by more than 11 million people on Instagram and 5 million followers on Twitter) becoming a reference for her ability to influence and mobilisation. Ofcom, the UK communications services regulator, conducted a survey in 2019 that identified an 18\% increase in children's access to social media aged 12 to 15 years to express support for environmental, political or environmental causes and social organisations , calling this increase the "Greta Effect" (Study developed by Ofcom, the company that is a regulator for the communications services (Tv, Radio and Video on demand sectors) in the United Kingdom, 2020), due to the activist's ability to mobilise other children to promote actions in defense of the environment.

In 2019, Greta was elected Ambassador of Consciousness by Amnesty International and person of the year by Time Magazine. She was also recently on the cover of Rolling Stone magazine, with a special issue on the climate crisis. In September 2019, the activist spoke at the opening of the Summit Meeting on Climate Action at United Nations headquarters, where she criticised the stance of world leaders for the lack of planning and mobilisation regarding the fight against the climate crisis. Greta's speech was widely disseminated on social media and traditional media (The 2019 UN Climate Action Summit was held at the headquarters of the United Nations in New York City on 23 September 2019. The UN 2019 Climate Summit convened on the theme, Climate Action Summit 2019: A Race We Can Win, 2019). In her speech, she states that:

„My message is that we'll be watching you. This is all wrong. I shouldn't be up here. I should be back in school on the other side of the ocean. Yet you 
all come to us young people for hope. How dare you! You have stolen my dreams and my childhood with your empty words. And yet I'm one of the lucky ones. People are suffering. People are dying. Entire ecosystems are collapsing. We are at the beginning of mass extinction, and all you can talk about is money and fairy tales of eternal economic growth. How dare you! [...] We will not let you get away with this. Right here, right now is where we draw the line. [...] You are failing us. But the young people are starting to understand your betrayal. The eyes of all future generations are upon you. And if you choose to fail us, I say: We will never forgive you. [...] The world is waking up. And change is coming, whether you like it or not" (Speech in the 2019 UN Climate Action Summit).

In the Instagram post of her speech, many people supported Greta's message, which was liked by more than 4 million users and had almost 142,000 comments. Messages from people around the world supporting Greta's speech were identified, with messages like "Greta is my biggest inspiration", "thank you for your work", "You and all future generations are worth fighting for". However, many messages considered offensive have been identified, such as "get a boyfriend", "she found an excuse not to go to school", "please, tell me, how do world leaders take your childhood at 16?". In most of the activist's posts, offensive comments are identified but mostly children and adults report the importance of Greta's actions and how she has inspired change around the world.

In July 2020, Greta received the prize from the Portuguese Foundation Calouste Gulbenkian for humanity of 1 million euros for the work she has done, and in a publication on Instagram, she informed that the entire value of the prize will be directed to organisations and projects that are fighting the climate and ecological crisis, especially for countries in the global south. The first 100,000 euros went to the Fridays for future Brasil project, the SOS Amazon campaign and the fight against COVID-19 in the northern region of the country, and the second organisation that also received the same amount went to the Stop Ecocide Foundation campaign, which seeks to make ecocide, that is, any human activity that causes data or massive destruction of ecosystems, an international crime.

Recently, Greta shared the release of the film I am Greta, available on the streaming platform Hulu, which follows the trajectory of the activist and her struggle for the environment. During a videoconference interview organised by the Venice Film Festival, Greta stated that "some people spread conspiracy theories, say that I do not think or speak for myself or that other people write my speeches. With this film, you can see that it is not true" (Interview conducted by The Guardian newspaper and published on September 4, 2020). In a publication on Instagram (Post posted on Greta Thunberg's Instagram profile about her documentary, 2020), she reinforces, since she received some questions about receiving money for the work, that there was no payment for any person involved in the documentary and that half of the amount received for the film will be donated to organisations and projects that defend the nature. 
"The movie I Am Greta will premiere today in cinemas across the United Kingdom, Germany, Austria, Switzerland, Belgium, Luxembourg, The Netherlands, Canada, Australia, and New Zealand. Next Friday also Italy and Mexico. And just to be clear once again: I - nor anyone in connection to me - have or will not receive any payment for this. B-Reel Films will dedicate half of the film's revenues to my foundation and all of that will be donated to organisations and projects fighting for a sustainable world, defending nature, and supporting people already facing the worst impacts of the climate- and ecological crisis".

But, Greta is not the only child who has been known for her activism. Dylan D'Haeze, a caucasian boy of 16 years old, is an American child (Washington/DC) who started producing a documentary about the environmental impacts of plastic on the Planet. Since he was 13, he has produced a series of documentaries called Kids Can Save The Planet (2020), seeking to make people aware of the environmental impacts caused by the unbridled use of the consumption of products that use it.

In July of 2020, he published the fourth documentary Political Climate: Vote for your Future, which seeks to raise awareness of the importance of elections as a way of coping with the climate crisis, as well as the role of children and young people in determining election results. In the comments, people thank the activist for his contribution to tackling the crisis, with messages like "This is just a Master Piece! I read the other day that California is experiencing record high temperatures, Death Valley 130 , that is some serious heat for our planet" and "Such an important and relevant topic". On his Facebook page, his project is followed by more than 2,227 people.

In the Netherlands, specifically in the city of Zeist, activist Lilly Platt, a caucasian girl of 12 years old, has been mobilising since she was 4 years old when she started collecting plastic items she found when walking to school to reduce the volume of plastic on the streets. Lilly has already given several lectures, including at TEDx, as an ambassador for HOW Global and youth in the Plastic Pollution Coalition. In an interview with The Guardian (Interview conducted by The Guardian newspaper with children climate activists, 2019), she tells her story and points out her concerns about global warming: „What happens to your body if you are $2^{\circ} \mathrm{C}$ above normal temperature? You feel very sick, so imagine how the planet will feel. We want world leaders, including Trump, to stay aligned with the Paris agreement, reduce carbon emissions and stay at $1.5^{\circ} \mathrm{C}$ from global warming. Polluters must pay".

On her Twitter account, she is followed by more than 12 thousand people on Facebook, her page has more than 4 thousand followers. In a publication where the activist criticised a supermarket that was selling peeled bananas wrapped in plastic with the hashtag \#pointlessplastic, there was a discussion about whether this strategy is valid for some situations. A user posted the message "keep in mind that this might make it easier for disabled people to eat pre-peeled fruit. There are other plastic freeways but don't be so quick to scorn pre-peeled fruit" and Lilly responded to the comment with "Thanks for your comment I am only raising awareness of plastic issues". In most posts, the activist reinforces through tips and 
information to make her followers aware of the importance of reducing plastic consumption in their daily lives.

Licypriya Kangujam, a nine-year-old indigenous girl, is also a climate activist from India who seeks to draw the attention of her country's population and leaders to find an urgent solution to the current air pollution crisis in Delhi and the National Capital Region. In 2018, she decided to create an organisation called The Child Movement (The Child Movement is a global movement for climate justice, providing free education to poor \& arm conflict victim children \& protecting child rights founded in July, 2018) to raise awareness to protect the planet, fighting climate change and natural disasters. Licypriya Kangujam has already given a lecture in 21 countries and at the age of six, she participated in the 3rd Asian Ministerial Conference on disaster risk reduction 2018 (AMCDRR 2018) in Ulaanbaatar, capital of Mongolia. In 2019, the activist was invited to deliver a speech at the COP25 Climate Conference in Spain, in her speech she reinforced the importance of taking action now against climate change. Licypriya Kangujam, when called in the mainstream media, Licypriya Kangujam posted on Twitter (2020a) a message warning about the importance of recognising her identity and activism.
„Dear Media,
Stop calling me "Greta of India". I am not doing my activism to look like Greta Thunberg. Yes, she is one of our Inspirations \& a great influencer. We have a common goal but I have my own identity, story. I began my movement since July 2018 even before Greta was started. I first raised my voice to world leaders in Mongolia in a UN event on July 4, 2018. Since then I started my movement called "Child Movement". In Hindi, we called it "Bachpan Andolan" to call our world leaders to take immediate climate action. As I felt my work is more important than the organization, I have less publicity and media coverage. Only media came to notice me when I spend a week in front of the Parliament House of India on July 21, 2019. Before that also, I began my Parliament Move- ment since Feb. 2, 2019. I even dropped out of my school since February 2019 (before the Grade 1 final exam) when I was just 7 years old due to my protests every week in front of the Parliament House of India. I sacrificed so much of my life at this tender age is not to called me "Greta of India". If you call me "Greta of India", you are not covering my story. You are deleting a story".

The idea disseminated in the media usually does not portray the individual trajectories and social and cultural contexts of children and presents a notion of a unique childhood, especially through a Eurocentric perspective, corroborating what is discussed by Walter D. Mignolo (2003), who states that "Eurocentrism works as if there were no outside of the canonical macro narratives of Western civilisation or European modernity since the Renaissance" (p. 665). The children's actions end up being made invisible not only by an adult-centric vision, which identifies childhood only from the protection of individuals who are in this category but also by the prism of Eurocentrism, giving priority to presenting the stories of white children and European countries (Chakrabarty, 2000). This publication was liked by more than 137 thousand people and shared more than 28 
thousand times on Twitter. She is followed by more than 139 thousand people on this social media. On her Instagram, she is followed by more than 13 thousand people. In the comments, most people supported the activist's message, with messages such as:

„I'm so proud of you and it's sad to see how commonly/easily women are compared to each other. I wish you the best of luck in your endeavours and hope that your activism as well as Gretas will inspire change.

Right, you are Licypriya, great and very brave, a great role model.

What you are doing in India will have a ripple effect across the globe! @ LicypriyaK you are an inspiration in your own right. Thank you for all you are doing to save our planet".

However, offensive comments targeting Licypriya were also identified as "It's not a competition. Stop whining" or "brat", "Your name is too difficult. We'll keep it simple by calling you Greta of India". In October 2020, the actions carried out by Licypriya in conjunction with her friend and activist Aarav Seth, 12, were censored by the police, as the activist was briefly detained for protesting in front of parliament against air pollution in the city of Delhi. On her Twitter (2020b) profile, the activist posted the following message:

So many police and security forces detained a 9 years old girl and a 12 years old boy. I'm raising my voice is not just for me, it's for the millions of children of Delhi and the people of this country. Our leaders just pretend but they don't take any concrete action yet.

The tweet had 1,500 likes and 112 comments. Again, the activist received messages of support and encouragement such as "\#StayStrong ... the future is in the hands of the brave and young", "Thanks for everything you do for us all", but other people, especially adults, wrote messages minimising Licypriya's actions.

Heyy kid...I like ur awareness abt the Environment nd Air pollution at that tiny age...U have $90 \mathrm{k}+$ followers On Twitter. Ask or plan at least min 100 to 50 followers, then protest seriously not seasonally...like $15 \mathrm{~min}$ or $30 \mathrm{mins}$.

$\mathrm{U}$ want publicity...If $\mathrm{u}$ really care nd serious abt issue, then protest in front of parliament without taking a break at least 2 or 3days...then the National media truly focus $\mathrm{U}$ nd then u give a so-called speech...

Keep Minor Children out of politics

It is worth noting that Licypriya's Twitter and Instagram accounts are managed, according to the information available in the biography, by the activist's mother, this parental control is important to avoid risky situations for the child since most platforms a Minimum age allowed is from 13 years old. Licypriya recently shared that she created a solar lamp built with bamboo (2021). The publication had over 1,600 likes and 38 comments, where messages like "Absolutely great and innovative. Environmental science or environmental engineering is the best branch for you to research. Innovate more and more", "Excellent. Keep doing such useful work". One user posted a "save trees" comment, being answered 
through the profile of the activist "Bamboo is not a tree dear. It's a grass and most sustainable materials found on this planet stronger than steel". Other followers commented on the doubt, but when they identified that it was a troll (users who use fake profiles to provoke members of a certain community on the social media), they stopped responding to the messages. It was possible to identify from digital ethnography, that children with the greatest number of followers and with the most visibility in the media are the ones that are most subject to offensive comments.

Another child who has also drawn attention for her actions about climate justice in Cape Town in South Africa is Yola Mgogwana, a african descendant girl of 13 years old. She is a member of the Earthchild Project (Earthchild Project is a Non-Profit Organisation operating in disadvantaged schools in Cape Town, South Africa. Working with children and teachers our educational programmes focus on the environment, health and life-skills. Retrieved August 19, 2021, from https:/ / earthchildproject.org/), which seeks to provide education with a focus on the environment, health, and self-development through few resources. In early 2019, she led and organized a protest in front of the South African parliament, where she spoke about the importance of government officials taking action to combat climate change. In an interview with the Global Citizen website (Global Citizen website and published on October 16, 2019), she says that even though she is so young, her age "does not mean that my opinions about the world are not valid". On the project page, Yola is identified as an "eco warrior", with publications on different actions that the activist has been promoting, especially on Fridays to combat the climate crisis

"Change comes from the voice of many, but you need individuals to stand together to create a collective. My age does not mean that my views on the world are not valid. I believe we are all accountable for what the future holds, regardless of age, race, or gender. I'm marching, singing, and shouting for my right to a livable future" ( Post posted on Earthchild Project' Instagram profile, 2020)

The project is followed by more than 10,000 people on Instagram and 11,000 people on Facebook. The page is not exclusive to the activist, but she is one of the main voices in the fight for climate justice in her country.

In East Africa, Leah Namugerwa, a 16-year-old african descendant girl, is a climate activist who has been promoting actions and mobilisations against the Uganda climate crisis. Following Greta's actions on strikes on Fridays and what was happening in her country, with prolonged drought and landslides in some regions, Leah decided to act locally also protesting and participating in the weekly school strike. In an account of her trajectory on the website Earth Day (Interview conducted by Earth Day, a formal campaign launched in Summer 2020, that combining grassroots support and on the ground efforts by students, educators, and nonprofits with national level commitments from Ministries of Education and Environment. Retrieved August 19, 2021, from https://www. earthday.org/school-strike-for-climate-a-day-in-the-life-of-fridays-for-futureuganda-student-striker-leah-namugerwa/), she states that she joined the Twit- 
ter to follow the actions of Fridays for future. Initially, the activist reported that some people were surprised by the action and did not understand Leah's choice not to go to school. According to her, "many people have been and still oppose my protests. They argue that at my age I shouldn't miss any school day". The activist further states that: "The silence about environmental injustice seems to be intentional. Most people don't care what they do with the environment. I realised that adults were not willing to offer leadership and I chose to volunteer. Environmental injustice is an injustice to me".

Currently, Leah has used her visibility on social media to organise food donations for the children most affected by the floods in some regions of the country and who have been infected by COVID-19. In a recent post on Twitter (Post posted on Leah Namugerwa's Twitter profile about the donations in Uganda, 2020), where she is followed by more than 26 thousand followers, she published: "Yesterday I gave food to 160 children. By the end of next week, I will provide (food) for a thousand children from 200 families. Today I am going to visit another community to make door-to-door deliveries. I am donating to children affected by Covid-19 and the floods. Thank you all for supporting me".

The publication had 199 likes and 6 comments, where all users congratulated the initiative and recommended strategies to avoid spreading the virus. In the mentioned publication, a user commented: "Very much appreciated. Though I believe there's a smarter approach you can adopt that reduces the kid's risk exposure to possible transmission - call in their parents to line up with disciplined physical distancing and personal sanitation measures. Focus more on suppression". The activist systematically publishes on her platforms, especially on Twitter, actions involving tree plantations and strategies to feed children in her country.

In Indonesia, two asian sisters, Melati Wijsen, 19, and Isabel Wijsen, 17, started the Bye Bye Plastic Bags (Bye bye plastic bags is a movement powered by youth around the world to say no to plastic bags that started in Indonesia, in 2013, by the sisters Melati and Isabel Wijsen. Retrieved August 19, 2021, from http://www.byebyeplasticbags.org/) campaign in 2013, when they were 15 and 13 respectively, intending to say no to the use of plastic bags in Bali. Initially, they started a petition, where they managed to collect almost 100,000 signatures to convince the Bali government to enact a ban on single use of plastic bags, achieving this goal in 2019. In Bali, a ban on the use of plastic bags was carried out, as well as straws and styrofoam. Melati and Isabel have already given several lectures, mobilisation actions to collect plastic garbage on the beaches and recently the activists were included in the Forbes list of 30 most promising young people under 30 (Post posted on Bye bye plastic bags's Instagram profile, 2020). In July 2020, the sisters shared on Instagram that they granted an interview to the NY Times to share the movement they have been carrying out, the Youthtopia project (Youthtopia is a new project from the teenage sisters behind Bye Bye Plastic Bags in Bali. It aims to train up a generation of changemakers and give them the tools to make a difference. Retrieved August 19, 2021, from https://youthtopia.world/), whose main objective is to provide training for young people to become agents of change. 
„HUGE NEWS! On today's @nytimes profile you will find our sister founders the first ever duo profile to be featured. Our story has grown into a massive movement that has been (and continues to be) the greatest teacher ever. Learning by doing. That's what we do! With all the knowledge and experience on the front line of change, we want to share this with more young people to become young changemakers. @youthtopia.world thank you to Richard, @ derael_on_timeand @nyimaslaula or being with us to capture this feature".

The publication was liked by more than 2700 people and had 39 comments congratulating the activists' work. Messages like "Melati and Isabel we are so proud and inspired by you! Thank you for all you do for this world", "Huge congrats + a huge thank you for inspiring the youth of all ages around the world to take action!" and "keep inspiring" have been identified. The sisters are followed by more than 60 thousand followers on this social media (Available in: https:/ / www.instagram.com/byebyeplasticbags/?hl=en ).

Inspired by Melati and Isabel, Amy Meek, 17 years old, and her sister Ella Meek, 15 years old (caucasians), from the United Kingdom (Nottinghamshire) developed a platform called KidsAgainstPlastic (is a campaign developed by thr sisters Amy and Ella Meek who already collected over 90,000 pieces of single-use plastic litter in the UK), which has, as a central principle, according to the campaign website, to contemplate the Global Objectives of the UN, specifically number 14: Conservation and sustainable use of oceans, seas and marine resources for sustainable development. Initially, they sought to present plastic water bottles to supermarkets in the region and, in parallel, collected more than 60,000 single use plastic items and developed an application to record this collection. In addition, the activists have already given a talk about the project at TEDx and claim that they have mobilised with several children across the UK who are facing plastic pollution together with them. In May 2020, activists published a book designed by them called "Be plastic clever", with tips on how to use plastic properly and how children can become activists (post posted on Kids Against Plastic's Twitter profile about the book publication, 2020): “IT'S PUBLICATION DAY! Be Plastic Clever is an embodiment of what Kids Against Plastic is all about, with information on plastic, tips on how to be \#PlasticClever, and ways other kids can be activists themselves. It's a book by kids for kids, and we can't wait for you to read it". The publication had more than 200 likes, 63 shares, and 10 comments. Activists received messages like "YAY!! Congratulations girls, it looks brilliant!","I had the pleasure to be at one of your inspirational talks. This is fantastic to see, a huge congratulations, keep doing what you're doing!",,'Well done guys keep up the good work I will be following you from now on to see how you're your plastic clear ups I'll go once again well done here are some pictures of our latest clear up 1000 plastic bags retrieved from Dorset Beauty Spot Google it". On Twitter, they are followed by more than 3,700 followers and on Instagram by more than 24 thousand followers.

Harriet O'Shea Carre, Milou Albrecht, and Callum Neilson-Bridgefoot, are three climate activists with 15-year-old (caucasians), residents of the city of Castlemain, Australia, and founders of the School Strike For Climate (SS4C) movement, which is followed on Instagram by 45 thousand people and on Twitter by 21.5 
followers. Inspired by Greta, they organised protests with over 300,000 people in Australia. In an interview with Dailymail Uk (Interview conducted by Dailymail Uk with Harriet O'Shea-Carre and published on September 24, 2019), Harriet stated that "children cannot vote, so that is the only way to change anything. It will be too late and people are literally dying". Like Greta, Harriet O'Shea Carre was invited to New York to attend the United Nations Climate Summit.

Harriet O'Shea Carre's speech reinforces what was presented by Manuel J. Sarmento, Natália Fernandes, and Catarina Tomás (2007), that children remain the only social group excluded from the political rights expressed in Western society (Sarmento, Fernandes, \& Tomás, 2007). The right to vote, usually from the age of 18 (in some countries it can be from the age of 16), rules out the possibility of children who are outside that age group participating effectively in the choice of political representatives. According to the authors, to think about the minimum age to voting, it is essential to reflect on a reorganisation of democracy, being essential not to analyse the political participation of children only through the power of voting, but, due to the absence of these individuals in political spaces (Sarmento, Fernandes, \& Tomás, 2007).

Childhood for Western society is understood as a protection stage in which the individuals that compose it are considered incapable of actively contributing to citizenship, since in most situations, adults tend to underestimate the actions of children, disregarding their opinions and evaluating what they think less importantly, even when they involve relevant topics that involve themselves (Tomás \& Fernandes, 2004). With this, the authors present three paradigms identified in the practices of adults towards children: Property Paradigm; Protection and Control Paradigm; Paradigm of Danger (Tomás \& Fernandes, 2004). The first refers to the way that adults subdue children, viewing them as property and using a paternalistic discourse to silence their voice and minimise their actions. The second paradigm is presented from an understanding that children must be controlled by adults and protected since they are considered fragile and incapable. Finally, it is evaluated how some deviant behaviour is evidenced by adults, who seek to use a penalising strategy for children even when considering their rights under the Constitution, yet these are circumscribed based on what adults consider relevant (Tomás \& Fernandes, 2004).

An example that can be presented to elucidate how children's voices have been constantly disqualified, refers to the offenses that Swedish climate activist Greta Thunberg received from the presidents of Brazil and the United States of America in 2019. Jair Bolsonaro referred to the child as "brat" (News released by The Guardian newspaper on December 10, 2019) (a pejorative term used in Brazil to refer to a child) by the activist's statement about her concern with the indigenous people who were being murdered for trying to prevent deforestation in the Amazon. Donald Trump, on the other hand, wrote in his social media that he considered Greta to have an "anger management problem" and "that she should relax" (News released by The Guardian newspaper on December 12, 2019). This statement by the American president referred to the choice of Time magazine to elect Greta as a personality of the year. The hate speech is very directed towards Greta because she is the most visible activist today. Thus, it is important to understand according to Cass Sunstein (1995), „,because of historical aspects, injuries directed at minority groups [...] feed 
the fear of physical violence, exclusion, and subordination that are not plausibly described as mere 'offenses'. These damages go against the goal of political equity, a precondition for democracy" (Sunstein, 1995, pp. 67-69).

After the statements, the activist changed her biographical description on Twitter with both offenses she received as a strategy to mock the criticisms that were made by the two heads of state. From these examples, it is possible to identify how children are still marginalised when seeking to participate in relevant social actions and how their voice is still silenced, being fundamental, as pointed out by Tomás and Fernandes (2004), rethink the aforementioned paradigms and identify children as active citizens and not just as rights holders, who can contribute and intervene in decisions made by adults.

For the authors "citizenship does not refer only to a legal right, but above all to a right to participate, a right that is related to the nature and social essence of the human being" (Tomás \& Fernandes, p. 354). To understand the child as a subject of rights, Fernandes (2005) points out the importance of adopting a paradigm that mutually contemplates the rights of provision (which guarantees access to health, education, culture, family life, etc.), of protection (preserve children from risky and vulnerable situations concerning neglect, physical and sexual abuse, conflicts, discrimination, etc.) and finally participation, recognising their political and civil rights (contemplating their right to be heard), to have an opinion, freedom of expression, identity, decision making, etc.). According to Ana Jorge and Lidia Marôpo (2017), children's right to participate online must be associated with four factors: , , [...] that the internet is a space for the promotion, protection, and consecration of human rights and the advancement of social justice; to seek, receive and transmit information freely; to associate freely with others for social, political and cultural reasons; and that internet governance is done with multiple parts, participatory and with shared responsibilities" (Jorge \& Marôpo, 2017, p. 4).

With this, it is essential that digital environments can increasingly reinforce in their terms of use principles that include human rights, access to truthful news, the privacy of users' data, and that mainly the platforms become an increasingly inclusive and safe space, especially for children, since they have been accessed by them regardless of the age allowed by these services.

\section{Conclusion}

The engagement of children and their struggles for their political and civil rights, according to Manfred Liebel and Lourdes Gaitán (2019) starts very early, and for the authors, the establishment of the actions carried out by this social group are influenced by the environment (militancy for example) and the need to seek justice for inequalities and social problems. However, the authors point out the importance of not reducing children's actions only as a result of the interests presented by adults, reinforcing that children's initiatives also arise from their considerations and experiences (Liebel \& Gaitán, 2019). The actions of the children mentioned above, reinforce that, based on the influence of their peers or their ini- 
tiative, they sought to express their dissatisfaction not only through social media but also by mobilising in person to seek answers from the authorities and society, even when this affects them negatively, such as missing school, being the target of fake news (News published by the media about fake news involving activist Greta Thunberg. Retrieved August 19, 2021) in addition to receiving offenses online. Liebel and Gaitán (2019) state that „, $[\ldots]$ when children defend a goal that affects them personally [...] they accept personal risks or disadvantages. The great resonance we find in other children and young people is probably influenced by this personal commitment. It is also related to the fact that images of their activities spread very quickly on the Internet and that the protagonists themselves helped in part to create a national audience on their blogs" (Liebel \& Gaitán, 2019, p. 17).

Through familiarity and experience with the use of technologies and social media, children and young people have been using online spaces and transforming them into activism practices, promoting in these new environments mobilisation, participation, organisation, and social leadership to fight for different causes. According to Lina Dencik and Peter Wilkin (2017), there was a great discussion on the relationship between protests through digital media and on how information and communication technologies (ICTs) allow people to organise themselves in different ways and places in a more accessible way and with low costs. For the authors, these environments have become a fundamental element of manifestation and resistance in the contemporary world, allowing wider, horizontal, and spontaneous dissemination of the practices that are carried out by activists worldwide. The association with a cause through these digital environments, which according to Suely Ferreira Deslandes (2018) can be permanent or temporary association, provides a new dimension to certain manifestations since, by the fast dissemination and fluidity in the geographical borders, people from different places in the world can communicate and articulate through these spaces.

Due to the social reach of the Internet, it is possible to identify that minority groups that have always been invisible, especially in traditional media, can enhance their voices and practices through digital environments (Ferreira, 2018). Children, who are part of these minorities, are not indifferent to this reality, using social media to share experiences, interests, and social issues that involve their daily lives. It is worth emphasising the importance of digital literacy so that access to these spaces is carried out safely and responsibly for this social group, being essential that the family, the school, and the organisations that manage these environments promote changes so that the digital rights of children's are contemplated.

With this, it is possible to identify from these and other examples of child activists that their productions and protagonism in the social media has promoted an expansion of participation and civic engagement of their peers, in addition to an awareness of which measures can be effective for significant social and political changes in different spheres, especially in combating the climate crisis. Children are competent in their form of participation and are important allies in any type of social movement. The path must be a process of integration of struggle and nonopposition between adults and children since they are always looking for strategies of resistance to talking about issues that they consider relevant. 


\section{REFERENCES}

[1] Chakrabarty, D. (2000). Provincializing Europe. Postcolonial thought and historical difference. Princeton \& Oxford: Princeton University Press.

[2] Dencik, L., \& Wilkin, P. (2017). Digital activism and the future of worker resistance. In: G. Meikle (Ed). The Routledge Companion to Media and Activism, Routledge Media and CulturalStudies (pp. 125-133). Companions, Routledge, London, England.

[3] Deslandes, S. (2018). Digital activism and its contribution to political decentralization. Science \& Collective Health, 23(10), 3133-3136.

[4] Dholakia, N. \& Zhang, D. (2004). Online qualitative research in the age of e-commerce: data sources and approaches. Forum: Qualitative Social Research, 5(2), 1-10.

[5] European Commission Eurydice (2017). Citizenship education at school in Europe 2017. Eurydice Report. Luxembourg: Publications Office of the European Union.

[6] Fernandes, N. (2005). Children's rights at the crossroads of protection and participation. Zero-a-Seis Electronic Magazine, 7(12), 1-10.

[7] Ferreira, N. (2018). Media arenas as a stage for minority struggles. Media and Daily Magazine, 12(1), 24-41.

[8] Jorge, A. \& Marôpo, L. (2017). Digital media and rights: Perspectives of young people with cancer. Public Communication, (12)22, 1-14.

[9] Kulp, S., Strauss, B. (2019) New elevation data triple estimates of global vulnerability to sea-level rise and coastal flooding. Nature Communications, (10) 4844, 1-12.

[10] Liebel, M. \& Gaitán, L. (2019). The power of boys and girls. Notes on the protagonism of children's movements today. Society and Childhood Magazine, 3, 15-20.

[11] Lundy, L. (2015). National Strategy on Children and Young People's Participation in Decision-Making. Ireland Department of Children and Youth Affair.

[12] Mignolo, W. (2003). Local Stories/Global Projects. Coloniality, subordinate knowledge and preliminary thinking. Belo Horizonte: Publisher UFMG.

[13] Miller, D., Costa, E., Haynes, N., McDonald T., Nicolescu, R., Sinanan, J., Spyer, J., Venkatraman, S. \& Wang, X.. (2016). How world changed social media. London: UCL Press.

[14] Murthy, D. (2008). Digital ethnography: An examination of the use of new technologies for social research. Sociology, 42(5), 5837-855.

[15] Rizzini, I. et al. (2005). Children's Perspectives on Citizenship and National-Building. Rio de Janeiro: CIESPI/ PUC-Rio.

[16] Rizzini, I. Thapliyal, N. \& Pereira, L. (2007). Perceptions and experiences of citizen participation of children and adolescents in Rio de Janeiro. Katál Magazine. Florianopolis (10), 164-177.

[17] Sarmento, M., Fernandes, N. \& Tomás, C. (2007). Public policies and child participation. Education, Society \& Cultures, 25, 183-206.

[18] Sunstein, C. (1995). Democracy and the problem of free speech. Publishing Research Quarterly, 11, 58-72.

[19] Tomás, C. \& Fernandes, N. (2004). Childhood, protagonism and Citizenship: contributions to a sociological analysis of childhood citizenship, Magazine Sociological Forum, 11(12), $349-361$.

[20] Unesco (2016). Planet: Education for environmental sustainability and green growth. The 2016 Global Education Monitoring Report (GEM Report). United Nations Educational, Scientific and Cultural Organization.

[21] Unicef (2013). Climate change: children's challenge. Climate Change Report 2013. Unicef, United Kigdom. 